\title{
Microstructural Properties of Natural Allophane/Gibbsite from a White Bauxite Deposit in Montenegro
}

\author{
Mira Ristić, ${ }^{1}$ Stjepko Krehula, ${ }^{1}$ Svetozar Musić ${ }^{1,2, *}$
}

\author{
1 Division of Materials Chemistry, Ruđer Bošković Institute, P.O. Box 180, HR-10002, Zagreb, Croatia \\ 2 Croatian Academy of Sciences and Arts, Trg Nikole Šubića Zrinskog 11, HR-10000 Zagreb, Croatia \\ * Corresponding author's e-mail address: music@irb.hr \\ RECEIVED: December 21, 2017 * REVISED: February 14, 2018 * ACCEPTED: February 19, 2018
}

\begin{abstract}
Microstructural properties of white bauxite from Montenegro were investigated. XRD analysis showed the presence of allophane $\left(\mathrm{Al}_{2} \mathrm{O}_{3} \cdot 2 \mathrm{SiO}_{2} \cdot 3 \mathrm{H}_{2} \mathrm{O}\right)$ and gibbsite $\left(\gamma-\mathrm{Al}(\mathrm{OH})_{3}\right)$. The allophane phase showed very broadened diffraction lines, thus indicating poor crystallinity as well as very fine nanoparticles in this phase. Upon heating of natural allophane/gibbsite at $1000{ }^{\circ} \mathrm{C}$ mullite $\left(\mathrm{Al}_{6} \mathrm{Si}_{2} \mathrm{O}_{13}\right)$ was formed, but with a lower degree of crystallinity. FT-IR spectra of allophane, gibbsite and mullite were interpreted. FE-SEM images of natural allophane/gibbsite showed a dominantly amorphous-like morphology. Upon heating of natural allophane/gibbsite two-dimensional (2D) microstructure was visible. EDS analysis showed traces of calcium, potassium, magnesium and iron. The ${ }^{57} \mathrm{Fe}$ Mössbauer spectrum of iron traces showed a small relative intensity magnetic splitting component due to the presence of hematite and a central quadrupole doublet due to the presence of Fe ${ }^{3+}$ ions substituted for $\mathrm{Al}^{3+}$ in octahedral positions and/or a superparamagnetic fraction of hematite particles. The possible geochemical mechanism of white bauxite formation in Montenegro is discussed.
\end{abstract}

Keywords: allophane, gibbsite, white bauxite, Montenegro.

\section{INTRODUCTION}

A LLOPHANE is a poorly crystalline hydrous aluminosilicate which is often present in volcanic ash soils. Discoveries of natural allophanes are common in Japan and New Zealand, USA, Canada, Indonesia, Sweden as well as in South America and Africa. In dependence on the geological history and environmental conditions natural allophanes show different degrees of crystallinity with a varying $\mathrm{Si} / \mathrm{Al}$ ratio. Generally, allophane consists of aggregates of very fine hollow spheres with diameters $\sim 3.5$ to $5 \mathrm{~nm}$.

Yoshinaga et al. ${ }^{[1]}$ reported on the formation of imogolite and allophane in association with soil derived from sedimentary rock such as sandstone. Wada ${ }^{[2]}$ investigated structural properties of soil allophanes with two endmembers of the compositions $2 \mathrm{SiO}_{2} \cdot \mathrm{Al}_{2} \mathrm{O}_{3} \cdot 3 \mathrm{H}_{2} \mathrm{O}$ and $\mathrm{SiO}_{2} \cdot \mathrm{Al}_{2} \mathrm{O}_{3} \cdot 2 \mathrm{H}_{2} \mathrm{O}$, and the structure of these allophanes was proposed. Allophane with the $\mathrm{Si} / \mathrm{Al}$ ratio $1 / 1$ consists of a silica tetrahedral chain and an alumina octahedral chain sharing a corner of the tetrahedron and octahedron, respectively. With the addition of another alumina octahedral chain to the silica tetrahedral chain allophane with the $\mathrm{Si} / \mathrm{Al}$ ratio 1:2 was formed. The XRD pattern of poor crystalline allophane was explained as a consequence of the differences in alignment of the above mentioned structural chains. Van der Gaast et al. ${ }^{[3]}$ also investigated the structure of allophane samples $\left(\mathrm{SiO}_{2} / \mathrm{Al}_{2} \mathrm{O}_{3}\right.$ ratio from 1.12 to 1.68 ) using small angle XRD and high-resolution electron microscopy.

The thermal treatment of allophanes caused structural changes due to condensation of $\mathrm{SiO}_{4}$ tetrahedra probably induced by a breakdown of $\mathrm{Si}-\mathrm{O}-\mathrm{Al}$ linkages and dehydroxylation of $\mathrm{Si}-\mathrm{OH}$ groups. ${ }^{[4]}$ Kitagawa ${ }^{[5]}$ also investigated dehydration of adsorbed water and structural hydroxyl groups in two natural allophane samples.

The functional groups ( $\mathrm{Si}-\mathrm{OH}$ and $\mathrm{Al}-\mathrm{OH}$ ) in allophane particles are responsible for their acid/base surface properties. Allophane and imogolite roles in soil 
biogeochemical processes were reviewed by Parfitt. ${ }^{[6]}$ In allophane soils phosphate anions are specifically and very strongly adsorbed and therefore the presence of allophane adsorbent in soils decreases the phosphorus uptake by plants. On the other hand, allophane can be used to remove high concentrations of phosphates from meat processing industry which make problems in water systems due to the eutrophication role of phosphates. ${ }^{[7]}$ Boron ${ }^{[8]}$ and arsenate ${ }^{[9]}$ adsorptions by allophane were also investigated.

In the present work we focused on the properties of natural allophane/gibbsite found in a deposit of white bauxite from Montenegro. Near this location there are high quality deposits of red bauxites (low $\mathrm{Si}$ content). The coexistence of red and white bauxites at the same geographical area is unique in the geochemical sense.

\section{EXPERIMENTAL}

The natural allophane/gibbsite from Vonjin Do, Trubjela, Montenegro was investigated.

XRD patterns were recorded using an APD 2000 diffractometer manufactured by Italstructures (GNRAnalytical Instruments Group, Italy). The CuKa radiation $(\lambda=0.15406 \mathrm{~nm}), 40 \mathrm{kV}$ high voltage and $30 \mathrm{~mA}$ current were applied. ICDD cards for allophane No. 38-0449, for gibbsite No. 33-0018 and for mullite No. 15-0776 were used.

FT-IR spectra were recorded using a FTIR-ATR spectrometer manufactured by Bruker.

Samples were also inspected with a thermal field emission scanning electron microscope (FE-SEM, model JSM 7000F) manufactured by Jeol Ltd. FE SEM was linked with an EDS spectrometer (INCA-350) manufactured by Oxford Instruments.

The RT Mössbauer spectrum of natural allophane / gibbsite sample was recorded using a spectrometer set-up from WissEl modules (Starnberg, Germany). The ${ }^{57} \mathrm{Co}$ in the Rh matrix was used as a Mössbauer source.

\section{RESULTS AND DISCUSSION}

Figure 1 shows the XRD pattern of natural allophane / gibbsite minerals found in a white bauxite deposit in Montenegro. Three main diffraction peaks of allophane $\left(\mathrm{Al}_{2} \mathrm{O}_{3} \cdot 2 \mathrm{SiO}_{2} \cdot 3 \mathrm{H}_{2} \mathrm{O}\right)$ in line with the ICDD card No. 38-0449 are positioned at $2 \theta=26.997^{\circ}(100 \%), 40.041^{\circ}(20 \%)$ and $66.763^{\circ}(10 \%)$. In the present case these are very broad peaks thus indicating poor crystallinity or/and the presence of very fine particles of allophane. In the same XRD pattern the gibbsite phase peaks are visible and they are in line with the ICDD card No. 33-0018. Figure 2 shows the XRD pattern of sample produced by heating natural allophane/gibbsite from Montenegro at $1000{ }^{\circ} \mathrm{C}$. The XRD pattern of this thermal decomposition product was assigned to mullite $\left(\mathrm{Al}_{6} \mathrm{Si}_{2} \mathrm{O}_{13}\right)$ in line with the ICDD card No. 15-0776.

Figure 3a shows the FT-IR spectrum of natural allophane/gibbsite sample. This spectrum shows IR bands (shoulders) which can be assigned to these phases, but overlapping of the corresponding bands is evident. Ming et al. ${ }^{[10]}$ discussed a possible presence of allophane on Mars and the relation to the thermal infrared (TIR) spectra of synthetic allophane. According to them, Si-rich allophanes have two broad absorption bands centred near $1080 \mathrm{~cm}^{-1}$ and $430 \mathrm{~cm}^{-1}$ from $\mathrm{Si}(\mathrm{Al})-\mathrm{O}$ stretching and $\mathrm{Si}(\mathrm{Al})-0$ bending vibrations, respectively, whereas Al-rich allophanes show three broad IR bands at 950, 540 and $430 \mathrm{~cm}^{-1}$. Reinert et al. ${ }^{[11]}$

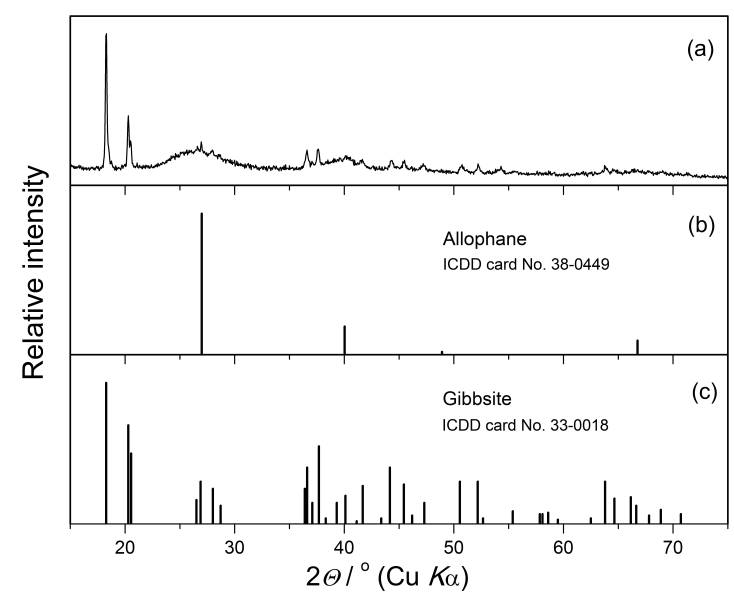

Figure 1. The XRD pattern of (a) natural allophane/gibbsite minerals from a white bauxite deposit in Montenegro, (b) allophane standard $\left(\mathrm{Al}_{2} \mathrm{O}_{3} \cdot \mathrm{SiO}_{2} \cdot 3 \mathrm{H}_{2} \mathrm{O}\right)$ and (c) gibbsite standard $\left(\gamma-\mathrm{Al}(\mathrm{OH})_{3}\right)$.

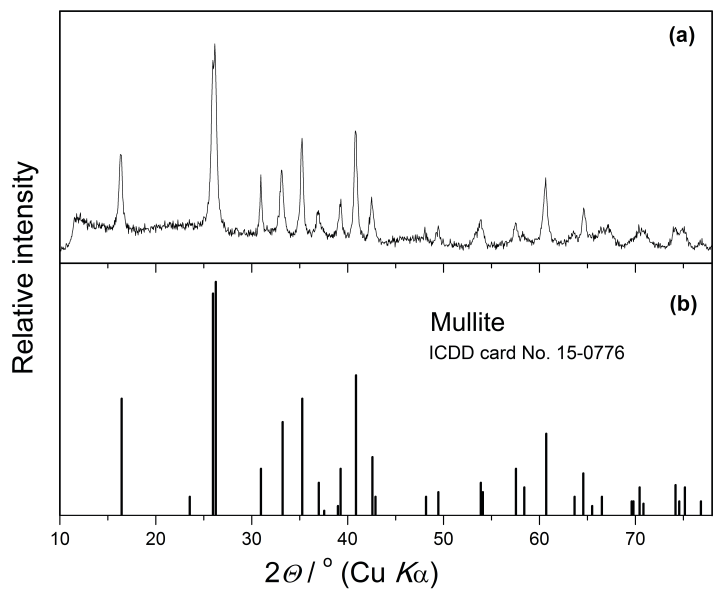

Figure 2. The XRD pattern of (a) mullite produced upon heating of natural allophane/gibbsite at $1000{ }^{\circ} \mathrm{C}$ and (b) mullite standard $\left(\mathrm{Al}_{2} \mathrm{Si}_{6} \mathrm{O}_{13}\right)$. 
recorded a broad IR band at $\sim 3500 \mathrm{~cm}^{-1}$ due to stretching $v_{(\mathrm{OH})}$ vibrations of adsorbed water and corresponding bending $v_{(\mathrm{OH})}$ vibrations at $1638-1639 \mathrm{~cm}^{-1}$. Allophane with the ratio $\mathrm{Si} / \mathrm{Al}=0.5$ showed a prominent IR band at $978 \mathrm{~cm}^{-1}$ with the shoulder at $858 \mathrm{~cm}^{-1}$ which was assigned to $\mathrm{Si}-\mathrm{O}-$ (Si) and $\mathrm{Si}-\mathrm{O}-(\mathrm{Al})$ stretching vibrations. For the ratio $\mathrm{Si} / \mathrm{Al}=$ 1 the IR band at $978 \mathrm{~cm}^{-1}$ was shifted to $995 \mathrm{~cm}^{-1}$. The IR bands at $\sim 422$ and $570 \mathrm{~cm}^{-1}$ for the $\mathrm{Si} / \mathrm{Al}=0.5$ ratio and 452 and $553 \mathrm{~cm}^{-1}$ for the $\mathrm{Si} / \mathrm{Al}=1$ ratio were assigned to the vibration of the allophane crystal framework. Nampi et al.[12] synthesised aluminosilicates with varying $\mathrm{Al}_{2} \mathrm{O}_{3}$ : $\mathrm{SiO}_{2}$ molar ratios $(3: 1,3: 2,3: 3$ and $3: 4)$ and treated them at different temperatures up to $1400{ }^{\circ} \mathrm{C}$. The FT-IR spectra showed broadening and shifts of IR bands for samples prepared at $800{ }^{\circ} \mathrm{C}$ and this was assigned to the restructuring of octahedral and tetrahedral positions of $\mathrm{Al}$ and $\mathrm{Si}$ atoms before mullite crystallization. The IR band at 560 $\mathrm{cm}^{-1}$ can be assigned to allophane, whereas Kitagawa ${ }^{[5]}$ noticed the same IR band at $570 \mathrm{~cm}^{-1}$.

Single-crystal Raman and FT-IR spectra of gibbsite were combined with the factor group analysis and it was concluded that $\operatorname{six} v_{(\mathrm{OH})}$ stretching bands can be expected to appear in the corresponding spectra. ${ }^{[13]}$ The interlayer hydrogen-bonded $\mathrm{OH}$ groups oriented along the $c$-axis of gibbsite crystals showed bands at 3433,3370 and $3363 \mathrm{~cm}^{-1}$, whereas the interlayer hydrogen-bonded $\mathrm{OH}$ groups

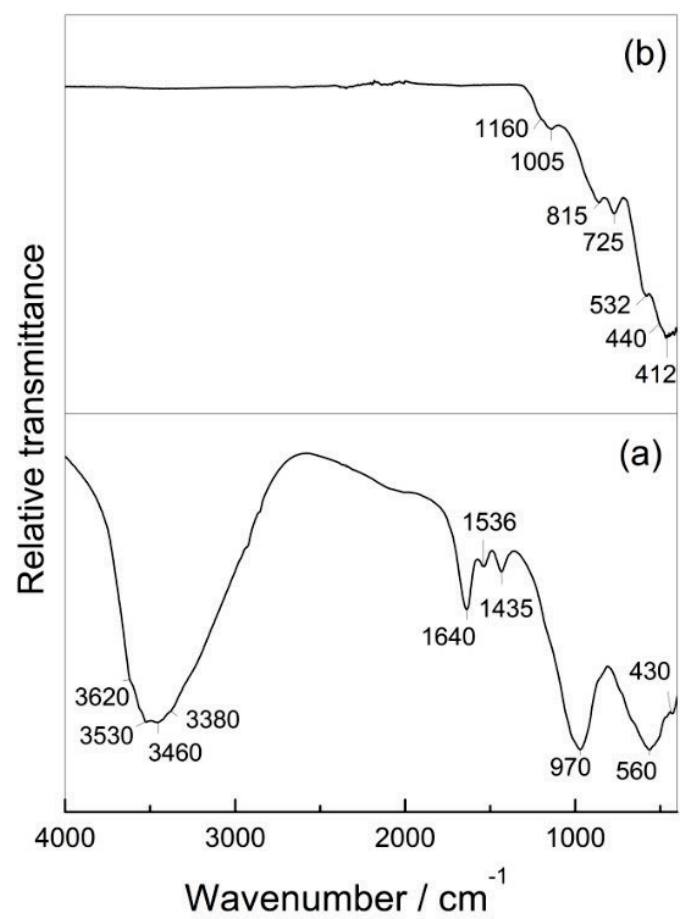

Figure 3. The FT-IR spectra of (a) natural allophane/gibbsite minerals and (b) mullite obtained upon heating of allophane/gibbsite at $1000^{\circ} \mathrm{C}$. oriented nearly parallel to the (001) plane showed IR bands at 3623,3526 and $3519 \mathrm{~cm}^{-1}$. Typical Raman bands of gibbsite $^{[14,15]}$ were positioned at 3617, 3522, 3433 and $3364 \mathrm{~cm}^{-1}$. In the present work the shoulders in the FT-IR spectrum (Figure 3a) were noticed at 3620, 3530, 3460 and $3380 \mathrm{~cm}^{-1}$ and these IR positions can be assigned to the gibbsite phase. Moreover, in this spectrum the typical IR bands corresponding to gibbsite were overlapped by stretching $v_{(\mathrm{OH})}$ vibrations of $\mathrm{H}_{2} \mathrm{O}$ molecules as well as with $\mathrm{Si}-\mathrm{OH}$ and $\mathrm{Al}-\mathrm{OH}$ groups from allophane. The IR band at $1640 \mathrm{~cm}^{-1}$ is due to the bending $v_{(\mathrm{OH})}$ vibrations of $\mathrm{H}_{2} \mathrm{O}$ molecules. The IR band at $1435 \mathrm{~cm}^{-1}$ is a $v_{3}$ fundamental vibration of adsorbed carbonate ion, while the IR band located at $1536 \mathrm{~cm}^{-1}$ can be assigned to a degenerate fraction of the $v_{3}$ vibration. ${ }^{[16]} \mathrm{Su}$ and Suarez ${ }^{[17]}$ noticed IR absorption bands of adsorbed carbonates on amorphous aluminium hydroxide $\left(\mathrm{Am}-\mathrm{Al}(\mathrm{OH})_{3}\right)$ at 1420 and $1490 \mathrm{~cm}^{-1}$. In the same work gibbsite adsorbed much less $\mathrm{CO}_{3}{ }^{2-}$ than $\mathrm{Am}-\mathrm{Al}(\mathrm{OH})_{3}$ and the $v_{3}$ vibration splitting was not noticed for the experimental conditions. Guckel et al. ${ }^{[18]}$ recorded two IR absorption bands at 1500 and $1421 \mathrm{~cm}^{-1}$ which were assigned to the $v_{3, \text { as }}$ and $v_{3,5}$ vibration modes of carbonate ions adsorbed on gibbsite.

Figure $3 \mathrm{~b}$ shows the FT-IR spectrum of sample obtained by heating natural allophane/gibbsite. This sample was assigned to mullite $\left(\mathrm{Al}_{6} \mathrm{Si}_{2} \mathrm{O}_{13}\right)$ on the basis of the XRD pattern as shown in Figure 2. The FT-IR spectrum shows IR band at $1005 \mathrm{~cm}^{-1}$ with a shoulder at $1160 \mathrm{~cm}^{-1}$ and those positioned at $815,725,532,440$ and $412 \mathrm{~cm}^{-1}$. Beran et $a l .{ }^{[19]}$ investigated dehydration and the structural development of mullite precursors using FT-IR spectroscopy. Mullite precursors were prepared from alkoxides $\mathrm{Si}\left(\mathrm{OC}_{2} \mathrm{H}_{5}\right)_{4}$ and $\mathrm{Al}\left(\mathrm{OC}_{4} \mathrm{H}_{9}\right)_{3}$ by the sol-gel procedure. The molar ratio of these precursors corresponded to $3 \mathrm{Al}_{2} \mathrm{O}_{3}$. $2 \mathrm{SiO}_{2}$. In line with the work by Beran et al. ${ }^{[19,20]}$ the IR bands at 1160 and $1005 \mathrm{~cm}^{-1}$ can be assigned to the $\mathrm{Si}-\mathrm{O}$ stretch $\left(\mathrm{SiO}_{4}\right)$, the one at $815 \mathrm{~cm}^{-1}$ to the $\mathrm{Al}-\mathrm{O}$ stretch $\left(\mathrm{AlO}_{4}\right)$ in plane, at $725 \mathrm{~cm}^{-1}$ to $\mathrm{T}-\mathrm{O}-\mathrm{T}\left(\mathrm{TO}_{4} ; \mathrm{T}=\mathrm{Si}, \mathrm{Al}\right)$ in plane, at 532 $\mathrm{cm}^{-1}$ to the Al-O stretch $\left(\mathrm{AlO}_{6}\right)$ and at $440-412 \mathrm{~cm}^{-1}$ to the $\mathrm{O}-\mathrm{Si}-\mathrm{O}$ band $\left(\mathrm{SiO}_{4}\right)$ and $\mathrm{Al}-\mathrm{O}-\mathrm{Al}$ band $\left(\mathrm{AlO}_{6}\right)$. Generally, IR bands recorded for mullite prepared around $1000{ }^{\circ} \mathrm{C}$ (proto mullite) can be shifted in relation to mullite ceramics fired at 1350 to $1450{ }^{\circ} \mathrm{C}$. These IR band shifts are caused by the small crystallite size, a structural disordering and a local deviation in stoichiometry in proto-mullite.

Figure 4 shows the FE-SEM images of $(a, b)$ natural allophane/gibbsite, and (c,d) mullite produced by heating this natural composite at $1000{ }^{\circ} \mathrm{C}$. The FE SEM images of $(a, b)$ allophane/gibbsite sample showed a dominantly amorphous-like morphology. On the other hand, mullite (or proto-mullite) produced at $1000{ }^{\circ} \mathrm{C}$ showed dominant twodimensional (2D) microstructures. The EDS analysis of this sample showed traces of $\mathrm{Ca}(0.18 \%), \mathrm{K}(0.40 \%)$ and $\mathrm{Mg}$ 
(0.44\%). Natural allophane/gibbsite also showed about less than $1 \%$ of iron in tiny veins of the iron containing phase(s). The ${ }^{57} \mathrm{Fe}$ Mössbauer spectrum of this brown/red tiny vein was recorded (Figure 5) and showed the superposition of central quadrupole doublet and sextet. The sextet showed the hyperfine magnetic field (HMF) value of $48.9 \mathrm{~T}$ which is a value smaller than that from literature data ( 51.8 T) ${ }^{[21]}$ for a well defined hematite. In the present case this can be explained by a possible substitution of trace elements into the hematite crystal structure or the presence of very fine particles (collapsing sextet). Central quadrupole doublet can be assigned to iron substituted for aluminium at octahedral sites and/or a small fraction of superparamagnetic hematite particles.

The origin of bauxites in Mediterranean countries was the subject of many discussions. It is generally accepted that Mediterranean red bauxites are of the boehmite-type. For example, one analysis of red bauxites from Montenegro showed the following mineralogical composition:[22] boehmite (65-67\%), gibbsite (5-6\%), hematite (17-18\%), rutile ( $3 \%)$, kaolinite and halloysite (7-8 \%) and calcite $(0.3 \%)$. Bárdossy ${ }^{[23]}$ discussed broadly the theory of terra rossa, i.e., the formation of bauxite deposits on carbonate rocks. The idea of terra rossa theory is based on weathering of limestone and dolomite rocks and a preconcentration of red bauxite. This theory was also considered by Burić[24]. On the other hand, Pajović[25] proposed a volcanogenic theory which takes into account the Al-Si parent material from volcanic ash (tuff) or Al-Si dust from lateritic weathering of rocks and soils. Our structural/microstructural analysis of white bauxite from Vonjin Do (geographic map No. 6 in Ref. [24]) showed the phase composition of allophane and gibbsite and this finding can support the volcanogenic theory ${ }^{[25]}$ of the formation of white bauxites as found at the above mentioned location.

Generally, the transformation of allophane and imogolite minerals to gibbsite occurs as a result of desilications in an open and strongly leaching environment. The associations of allophane and gibbsite are found in many volcanic ash soils and pumice beds.
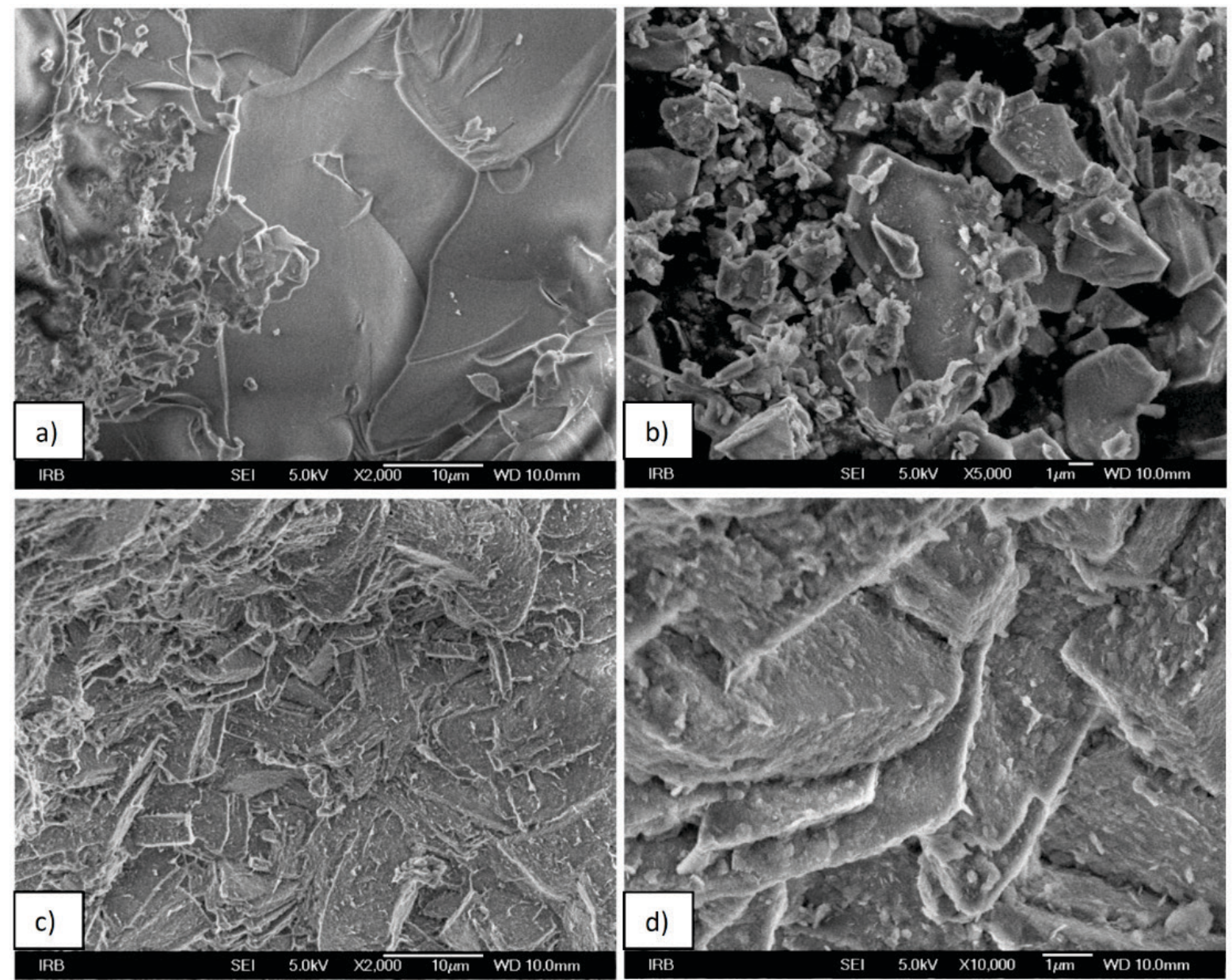

Figure 4. FE-SEM images of ( $a, b)$ natural allophane/gibbsite minerals (different magnifications), and (c,d) of mullite produced upon heating natural allophane/gibbsite at $1000^{\circ} \mathrm{C}$ (different magnifications). 
Allophane and imogolite precipitate preferentially in a weathering environment where the water phase has $\mathrm{pH}$ $\sim 5$ to 7 . Chemical weathering and the corresponding phase transformations of volcanic ash (tuff) can be generally shown in several sequences, as follows: allophane/imogolite $\rightarrow$ halloysite $\rightarrow$ kaolinite $\rightarrow$ (gibbsite, goethite, hematite) $\rightarrow$ laterite. Intensive chemical weathering of volcanic glasses and ashes is primarily induced by the gaseous emission of anhydrides of chloride, nitrate and sulphate acids during the volcanic activity. Gardner ${ }^{[26]}$ concluded that gibbsite does not precipitate as a result of the dissolution of kaolinite unless quartz is absent from the geological system. This conclusion is in line with the fact that bauxites do not readily form on quartz-rich rocks. It has also been established that for gibbsite crystallization from amorphous $\mathrm{Al}(\mathrm{OH})_{3}$, the minimum $\mathrm{pH} \sim 5.6$ and the maximum initial concentration of total dissolved silicon less than $10^{-6.3}$ moles per liter are needed. In nature and in the laboratory mutual coagulation of fine gibbsite and silica particles (or corresponding $\mathrm{Al}-$ and Si-hydroxy polymers) is possible. $\mathrm{pH}_{\text {iep }}$ values at $\mathrm{pH} \sim 8$ to 10 were measured for gibbsite particles ${ }^{[27]}$ of different origin and for silica at $\mathrm{pH}$ between 1.7 and 3.5 ${ }^{[28]}$. Musić et al. ${ }^{[29]}$ synthesised amorphous $\mathrm{SiO}_{2}$ nanoparticles and measured their $\mathrm{pH}_{\mathrm{PZC}}=1.7$ using microelectrophoresis. Macias Vazguez ${ }^{[30]}$ investigated the presence of gibbsite in soils and saprolites of Galicia, NW Spain, and its formation by weathering of various aluminosilicates, especially plagioclases. The presence of gibbsite in deeper layers of deposits was explained by complexing $\mathrm{Al}^{3+}$ with biomolecules, thus increasing $\mathrm{Al}^{3+}$ mobility.

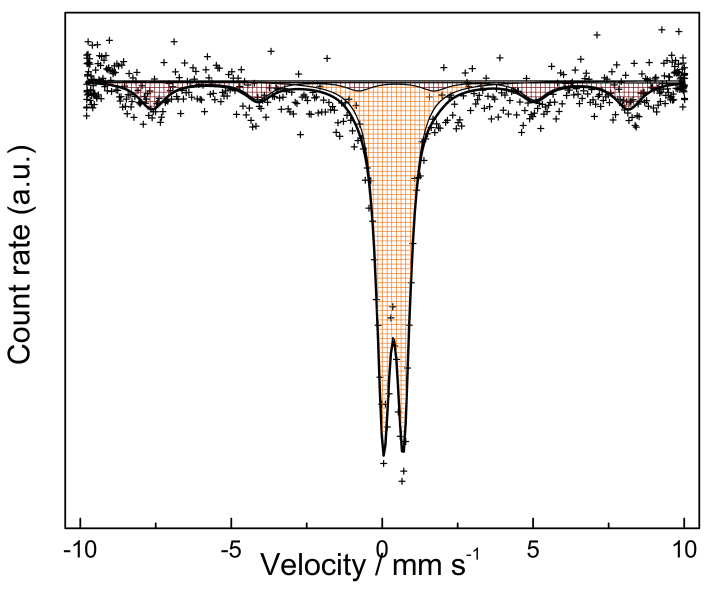

Figure 5. The RT Mössbauer spectrum of a tiny brown/red vein from natural allophane/gibbsite (sextet (25,9\%); IS $=0.37 \mathrm{~mm} \mathrm{~s}^{-1}, \mathrm{QS}=-0.20 \mathrm{~mm} \mathrm{~s}^{-1}, \mathrm{HMF}=48.9 \mathrm{~T}, \mathrm{LW}=$ $1.09 \mathrm{~mm} \mathrm{~s}^{-1}$; doublet $(74.1 \%)$; IS $=0.37 \mathrm{~mm} \mathrm{~s}^{-1}$, QS $=$ $0.66 \mathrm{~mm} \mathrm{~s}^{-1}$, LW $=0.53 \mathrm{~mm} \mathrm{~s}^{-1}$ )

\section{CONCLUSION}

The microstructural properties of natural allophane/gibbsite from a white bauxite deposit in Montenegro were investigated using XRD, FT-IR, FE SEM/EDS and ${ }^{57} \mathrm{Fe}$ Mössbauer spectroscopy. Very broad XRD lines were assigned to the allophane phase of poor crystallinity, consisting of very fine nanoparticles. Three main diffraction lines can be assigned to allophane with the formula $\mathrm{Al}_{2} \mathrm{O}_{3} \cdot 2 \mathrm{SiO}_{2} \cdot 3 \mathrm{H}_{2} \mathrm{O}$. Gibbsite $\left(\gamma-\mathrm{Al}(\mathrm{OH})_{3}\right)$ was identified as an additional crystalline phase to allophane. Heating at $1000{ }^{\circ} \mathrm{C}$ of natural allophane / gibbsite from Montenegro yielded mullite $\left(\mathrm{Al}_{6} \mathrm{Si}_{2} \mathrm{O}_{13}\right)$ which was not well crystallized (proto-mullite). The formation of well crystallized mullite ceramics can be obtained at 1350 to $1450{ }^{\circ} \mathrm{C}$. The FT-IR spectra confirmed the results obtained from XRD. The FE-SEM images of natural allophane/gibbsite showed a dominantly amorphous-like morphology, whereas upon heating at $1000{ }^{\circ} \mathrm{C}$ the twodimensional microstructure was visible. EDS showed traces of calcium, potassium, magnesium and iron. The RT ${ }^{57} \mathrm{Fe}$ Mössbauer spectrum recorded for a preconcentrated thin vein (brown/red in colour) from allophane/gibbsite sample showed the superposition of one sextet and central quadrupole doublet. The sextet was due to the presence of a hematite phase, whereas the central quadrupole doublet was assigned to $\mathrm{Fe}^{3+}$ ions substituted for $\mathrm{Al}^{3+}$ at octahedral positions and/or a fraction of superparamagnetic hematite particles. In spite of the fact that there are some uncertainties concerning the formation of allophane/gibbsite minerals, the volcanogenic origin of these minerals in white bauxite deposits from Montenegro can be generally presumed.

\section{REFERENCES}

[1] N. Yoshinaga, M. Nakai, T. Minagawa, T. Henmi, Soil Sci. Plant Nutr. 1984, 30, 555

[2] K. Wada, Am. Mineral., 1967, 52, 690.

[3] S. J. Van Der Gaast, K. Wada, S.-I. Wada, Y. Kakuto, Clays Clay Miner. 1985, 33, 237.

[4] T. Henmi, K. Tange, T. Minagawa, N. Yoshinaga, Clays Clay Miner. 1981, 29, 124

[5] Y. Kitagawa, Am. Mineral. 1974, 59, 1094.

[6] R. L. Parfitt, Clay Minerals 2009, 44, 135.

[7] G. Yuan, L. Wu, Sci. Technol. Adv. Mater. 2007, 8, 60.

[8] C. Su, D. L. Suarez, Soil Sci. Soc. Am. J. 1969, 61, 69.

[9] Y. Arai, D. L. Sparks, J. A. Davis, Environm. Sci. Technol. 2006, 39, 2537.

[10] D. W. Ming, E. B. Rampe, M. D. Kraft, T. G. Sharp, D. C. Golden, P. C. Christensen, Conference paper AGU (American Geophysical Union) Fall Meeting 2010, 13-18 Dec. 2010., San Francisco, California. 
[11] L Reinert, F. Ohashi, M. Kehal, J.-L. Bantignies, C. Goze-Bac, L. Duclaux, Appl. Clay Sci. 2011, 54, 276.

[12] P. P. Nampi, P. Moothetty, F. J. Berry, M. Mortimer, K. G. K. Warrier, Dalton Trans. 2010, 39, 5101.

[13] S. Li Wang, C.T. Johnston, Am. Mineral. 2000, 85, 739.

[14] H. Ruan, Spectroscopic Studies of Nano-Structures of $A$ I and Fe Phases, Bauxite and Their Thermally Activated Products, PhD Thesis, Queensland University of Technology, Australia, 2005.

[15] H. D. Ruan, R. L. Frost, J. T. Kloprogge, J. Raman Spect. 2001, 32, 745.

[16] H. H. Adler, P. F. Kerr, Am. Mineral. 1963, 48, 839.

[17] C. Su, D. L. Suarez, Clays Clay Miner. 1997, 45, 814.

[18] K. Guckel, A. Rossberg, V. Brendler, H. Foersendorf, Chem. Geol. 2012, 326-327, 27.

[19] A. Beran, D. Voll, H. Schneider, J. Eur. Ceram. Soc. 2001, 21, 2479.

[20] D. Voll, P. Angerer, A. Beran, H. Schneider, Vib. Spectrosc. 2002, 30, 237.

[21] E. Murad, J. Cashion, Mössbauer Spectroscopy of Environmental Materials and Their Industrial
Utilization, Kluwer Academic Publishers, 2004, 413 pps.

[22] N. Perović, Bauxites, Alumina and Aluminium, The Society for Science and Arts of Montenegro, Monographs, Vol. 6, Section of Natural Sciences, 1975, 109 pps.

[23] G. Bárdossy, Karst Bauxites: Bauxite Deposits in Carbonate Rocks, Academiai Kiado, Budapest 1982, 441 pps.

[24] P. Burić, Geology of bauxite deposits in Montenegro, The Geological Survey in Sarajevo, Sarajevo 1966, 279 pps.

[25] M. Pajović, Iranian J. Earth Sci. 2009, 1, 44.

[26] L. R. Gardner, Am. Mineral. 1970, 55, 1380.

[27] G. V. Franks, Y. Gan, J. Am. Ceram. Soc. 2007, 90, 3373.

[28] Isoelectric point determination, Application Note AN195, HORIBA Instruments, Inc., Irvine, Ca. 92618 USA.

[29] S. Musić, N. Filipović-Vincenković, L. Sekovanić, Braz. J. Chem. Eng. 2011, 28, 89.

[30] F. Macias Vazquez, Clay Minerals 1981, 16, 43. 